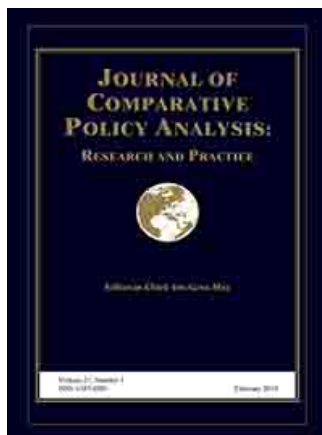

Journal of Comparative Policy Analysis: Research and Practice

\title{
Varieties of Regulation and Financialization: Comparative Pathways to Top Income Inequality in the OECD, 1975-2005
}

\section{Eoin Flaherty}

To cite this article: Eoin Flaherty (2019) Varieties of Regulation and Financialization: Comparative Pathways to Top Income Inequality in the OECD, 1975-2005, Journal of Comparative Policy Analysis: Research and Practice, 21:1, 90-115, DOI: 10.1080/13876988.2017.1416827

To link to this article: https://doi.org/10.1080/13876988.2017.1416827

View supplementary material $\nearrow$

曲 Published online: 02 Feb 2018.

Submit your article to this journal $\pi$

W Article views: 311

Q View related articles $₫$

View Crossmark data $\nearrow$ 


\title{
Varieties of Regulation and Financialization: Comparative Pathways to Top Income Inequality in the OECD, 1975-2005
}

\author{
EOIN FLAHERTY \\ School of Sociology, University College Dublin, Dublin, Ireland \\ (Received 4 October 2016; accepted 23 November 2017)
}

\begin{abstract}
With financialization now acknowledged as one of the most potent threats to income equality, can finance-driven inequality be explained by a singular causal argument? Taking the case of top incomes across the OECD, this paper addresses the standard causal narrative of financedriven inequality, where rising top income inequality is explained as a function of deregulation, financial sector growth, and a parallel weakening of the role of trade unions and the government. Applying fuzzy-set Qualitative Comparative Analysis (fsQCA) to a time-series dataset (1975-2005), it assesses the ways in which configurations of institutions combined in different ways prior to the recent financial crisis, to create policy contexts conducive to top income growth. It does this by adopting a time-series approach to QCA, involving calibration and analysis of data at three successive historical waves. Results suggest that top incomes in the era of finance-driven capitalism were subject to a diversity of causal paths which generated similar outcomes in different contexts, in a manner which departs substantially from the standard narrative. In doing so, it elaborates on the application of time-series approaches to case-based analysis, and uses its results to discuss the ways in which institutions may combine in different ways to generate similar, or divergent outcomes.
\end{abstract}

Keywords: time-series qualitative comparative analysis; financialization; income inequality; top incomes; comparative; sociology

\section{Introduction: Institutional Determinants of Inequality: How Does Social Policy Make you Richer?}

We live in a world of unprecedented inequality. In a pattern repeated across many capitalist democracies, the wealthiest US earners have quadrupled their incomes since 1979, with one-third of those now drawn from executive, managerial, and supervisory occupations (Kenworthy 2017). Since the financial crisis, the fortunes of top earners are returning to steady growth, whilst the public fallout from the economic crash is still generating debate about how to prevent its proximate causes from wreaking havoc once

Eoin Flaherty is Assistant Professor at the School of Sociology, University College Dublin. His work explores how regulatory institutions and power resources influence the income shares of the top 1 per cent, and the distribution of national income between capital and labour.

This paper is part of the special issue titled "Methodological Challenges for Comparative Welfare State Research: Capturing Intra-country Variation in Cross-national Analyses" with guest editors Rossella Ciccia and Jana Javornik. Correspondence Address: Eoin Flaherty, School of Sociology, University College Dublin, Dublin, Ireland. Email: eoin.flaherty@ucd.ie 
again. A large body of literature now points toward the process of "financialization" both as a precondition for the financial crisis, and as a stressor of income equality, with specific benefits for top earners. The concept points to the qualitatively different opportunities for income generation linked to the financial sector which have emerged in recent decades, and the institutional changes which render it distinct from previous phases of capitalism (Foster and Holleman 2010). Financialization is thus characterized by rising shares of total economy Gross Value Added (GVA) accruing to the financial sector, deregulation of global capital flows, greater accrual of profit through financial, rather than commodity channels, and widespread access to cheap credit (van der Zwan 2014).

Rather than offering universal economic benefits through greater economy-wide productivity, its gains have been narrowly concentrated, contributing to a decline in economic growth, and an increase in inequality (Flaherty 2015; Tomaskovic-Devey et al. 2015). As such, the process of financialization is often viewed as mediated strongly by policy. This has variously occurred through fiscal, economic, social, and regulatory policy decisions enacted either by governments or trans-national compacts and treaties, coupled with "supply-focused" growth policies which favour the deregulation of capital and labour, and growth of financial sectors. The standard narrative of inequality thus views financedriven top income growth as a cumulative result of shifting power resources from labour to capital, producing substantial top compensation opportunities within financialized firms. This process was in turn facilitated by regulatory architectures which privilege the free movement of capital central to the financialization process, and the removal of states from labour market regulation and public investment (Kus 2012; Volscho and Kelly 2012; Lin and Tomaskovic-Devey 2013; Stockhammer 2013; Flaherty 2015).

This article investigates further this "classic" narrative of inequality, by examining the institutional diversity which underpinned top income inequality in a sample of Organization for Economic Co-operation and Development (OECD) countries. It traces the presence and applicability of this classic narrative at a number of points in time from the 1970 s to just before the financial crisis. A strong case exists for a specific focus on "the 1 per cent" as a distinct aspect of inequality, and a key outcome of the financialization process. The class homogeneity of the 1 per cent is suggested by their access to rental income, dividends, and investment yields - resources generally denied to the working population at large (Epstein and Power 2003; Alvaredo et al. 2013; Kus 2016). National context plays a central role in facilitating top income accumulation. As the composition of wealth has changed over time (such as housing displacing land as a basis of wealth from the nineteenth to twentieth centuries), so too did pre-crisis financial deregulation offer new opportunities for resource-endowed individuals to leverage greater personal returns (Piketty 2014; van der Zwan 2014).

Kim et al. (2015) have shown how inter-earner networking incentivized competition amongst Chief Executive Officer (CEOs), complementing Piketty's (2014) conclusion that reductions in top marginal tax rates played a key role in spurring a "take off" in top compensation since the 1970s. The mechanisms of this process are poorly understood, however. Regression-based methods predominate in the studies of the financializationinequality connection (Kus 2012; Stockhammer 2013; Flaherty 2015), and the estimation of complex interactions is difficult in a panel context - more of which below. As such, less attention has been given to the underlying diversity of case types which make up the panels on which these studies are based. This is not an inherent limitation of a panel approach - as the estimation of partial effects is essential to strategizing for change. Instead, it reflects the general neglect of causal complexity in the political economy 
literature - partly methodological, and partly conceptual, insofar as analysis often leans on sets of variables embedded in formal theories, and sourced with wide consensus.

This study addresses this omission by subjecting a set of pooled time-series cross-section data to repeated cross-sectional fuzzy-set Qualitative Comparative Analyses (fsQCA). Its aims are twofold: (1) to explore the prevalence and applicability of the "classic causal combination" of rising top income inequality by exploring potential diversity in the mix of conditions leading to top incomes; and (2) to further embed case-based methods in the regression-based political economy literature, by suggesting they become complementary strategies in the task of causal mapping. It begins by detailing the institutional conditions on which variation in experiences of financialization may occur, both across countries, and within countries over time. Second, it outlines the relative merits of case-based and panel methods for addressing longitudinal variation, followed by an application of fsQCA to a panel of capitalist democracies from 1975 to 2005.

\section{The Diverse Institutional Channelling of Financialization}

The direction of inequality in the pre-crisis years is well understood. In a pattern repeated for other measures of inequality such as labour's share of GDP and the Gini personal income distribution, top incomes enjoyed remarkable growth across many countries during the late 1990s/early 2000s (see Figure 1). This pattern has been

Figure 1. Top income shares across the OECD, 1975-2005

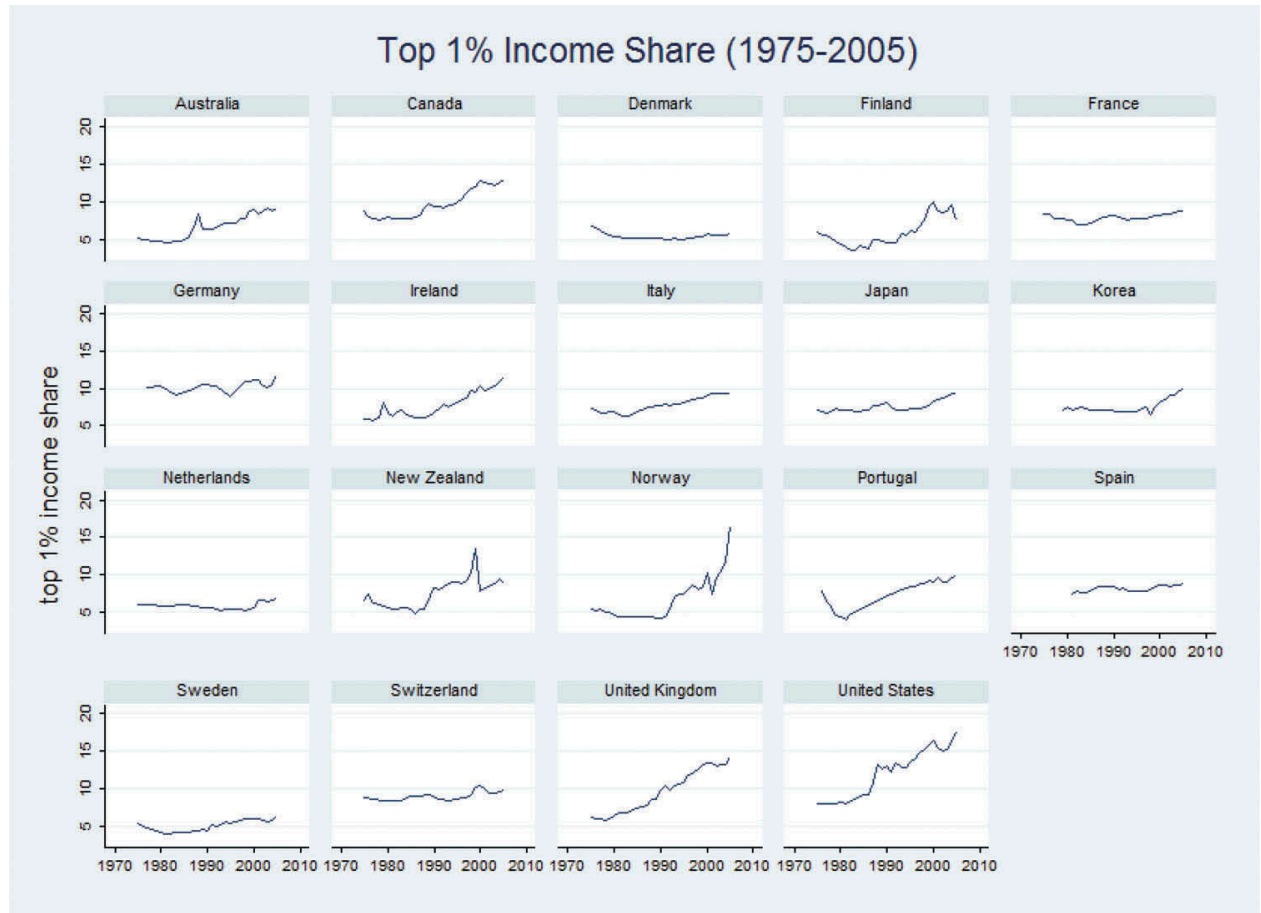


interpreted by Social Structures of Accumulation (SSA) analysts as driven by stark changes in the character of economic regulation in the post-war era (Kotz 2003; McDonough et al. 2010; Jessop 2013). In this perspective, the 1980s are viewed as a crucial policy juncture, with a loosening of regulatory constraints on capital, supplanting of real wages with cheap credit, privatization of public services, and a withdrawal of the state from labour market regulation (Tabb 2010). Accordingly, top incomes were free to flourish under this regime, whilst wider incomes stagnated.

How might experiences of financialization have varied across countries, and did the factors of financialization necessarily result in greater top income inequality? As to why countries experience greater or lesser degrees of inequality, several standard narratives are often invoked. Theories which allocate countries to various "worlds" of capitalism have emphasized the capacity of coordinated market economies/social democracies to effect greater equality of outcome due to more centralized and extensive collective bargaining, and a stronger role for the state (Ebbinghaus and Manow 2001; van Rie et al. 2011). Meso-level factors linked to national varieties of capitalism also play a role. At firm level, post-Keynesian theorists note that the latitude available to firms to pursue profit over growth, and to exert control over working conditions, is rooted in wider regulatory contexts (Stockhammer 2004, p. 723; Thompson 2013). Considering this potential diversity, one important omission of the financialization literature appears to be the uniformity with which it is applied to processes of longterm global policy change.

Studies suggest that the European path to financialization may be distinct, due to specific sets of drivers linked to European integration. From 1975 to 2005, many European banks loosened their historical ties to industrial "patient capital", increasing exposure to high-yield market-based financial instruments (Ó Riain 2012). This merely hastened deregulation in the interests of private capital, and the elimination of stability mechanisms, such as currency devaluation (Ó Riain 2014, p. 116). This would prove a crucial determinant of the incentive structure which permitted top earners to leverage higher compensation, as well as a structural precursor to the erosion of workers' bargaining power (Thompson 2013). Policy convergence thus played a key role in Europe's experience, curtailing national actors' abilities to effect policy change (Beckfield 2006, 2009; Becker and Jager 2010). In terms of post-crisis responses, we also see evidence of substantial variation in responses between OECD members. Greater post-bailout burden sharing between the public and private sectors has been noted in certain countries (Grossman and Woll 2014), whilst others have suggested that the institutions of the Eurozone amplified the causes of the crash, by enhancing rather than mitigating competition between European "core and peripheral" countries (Becker and Jager 2010; Bruff and Horn 2010).

Thelen $(2012,2014)$ is a strong critic of uniform liberalization narratives, and although not addressing financialization specifically, her argument can be readily extended. According to Thelen, experiences of liberalization vary more than the worlds of capitalism literature suggests, where it is often theorized as a drift from coordinated to liberal market structures, with attendant distributional consequences. Thelen challenges this view by emphasizing how liberalization depends very much on the "coalitional foundations" on which economic institutions rest. Her work complicates the encompassing narrative of international liberalization, showing how it can occur through processes of deregulation, dualization, or flexibilization (Thelen 2012, p. 8). This complexity is a welcome corrective 
to varieties of capitalism, but to speak of distributional consequences in this context is often to speak of personal inequality (i.e. amongst labour) (Rueda and Pontusson 2000). Furthermore, the underpinning "coalitional foundations" approach typically focuses on the staples of economic sociology - labour markets, sectoral employment shares, and industrial relations policy. As such, models like Thelen's focus more on "labour in general" rather than high net worth individuals who are often not immediately dependent on labour markets, or earned income.

It also downplays the broader divide in economic rewards between capital and labour, a key factor in finance-driven inequality. Therefore, whilst globalization is interpreted in this framework as empowering mobile capital relative to nationally anchored unions, financial capital is a distinct phenomenon. It empowers not only capital-endowed incumbents via instruments not linked to direct production, but can also dictate corporate strategy by incentivizing shareholder managerialism. The financial sector itself also does not "behave" like others, with its high productivity resulting from capital intensity and comparatively low employment. It is therefore less certain how the sector is subject to influence from the "coalitional foundations" which are principally dealt with in this literature in terms of their impact on conventional economic sectors - services, retail, manufacturing. Finally, the sector is less subject to typical national varieties of regulation. Financialization, as it has worked through the European banking system, has weakened the significance of national borders, as evidenced in the extent of inter-firm lending preceding the financial crisis. This can render finance substantially independent of domestic regulation, weakening the applicability of liberalization narratives which still rely on their fit with the characteristics of nations.

This perspective thus challenges uniform narratives which view liberalization (to which we might add financialization) merely as a secular movement from a greater to lesser role of the state in terms of capital, product, and labour market regulation. As such, it remains to be explored whether the conditions typically associated with financialization inherently give rise to greater inequality. As the foregoing section suggests, the variance across countries is likely to be extensive, and variation in the extent of interest groups, degree of corporatism, flexible labour market policies, wage bargaining coordination, and state intervention in markets, are all likely to moderate inequality outcomes (Kenworthy 2010; Mahoney and Thelen 2009). Such is the objective of this paper - to explore the various configurations of institutions associated with top income inequality and their potential variation over different time periods, and to square these findings with the wider theoretical literature on processes of financialization/liberalization. The following section begins this task by detailing how the data structures most commonly used to examine these processes have been handled in the political economy and policy literatures.

\section{Time Beyond the Methodological Divide: Panel vs Case-Based Methods}

Pooling cross-sectional data over time is a common approach to the study of income inequality from a political economy perspective (Kristal 2010; Kus 2012; Stockhammer 2013; Flaherty 2015; Tomaskovic-Devey et al. 2015). They are especially useful for testing whether relations between variable sets are time-dependent, what the nature of such time effects might be (short or long term for example), or 
whether significant historical events (structural breaks) play a role in driving variation in the outcome. The preceding section has raised the question of uniformity in the policy and institutional changes most commonly associated with financialization, and how these may be linked to greater top income inequality. This is inherently a question of cross-unit causal complexity, as our discussion has also set out some tentative explanations for how cross-unit divergences may arise.

Can such complexity be captured by a regression-based approach alone, and are regression and case-based approaches commensurable or substitutable? Byrne (1998) and Thiem et al. (2016, p. 764) caution that "neither do saturated interaction models integrate conjunctions ... nor can conjunctions be conceptually mimicked by interactions". Although the wider literature is divided on their relative merits, Thiem et al. are emphatic that both deal with fundamentally different causal logics - one formed of multidimensional property spaces, the other of linear algebraic expressions. In short, it is not enough for the analyst to justify choosing QCA due to difficulties in specifying and interpreting higher-order interactions in a panel regression.

What are the specific advantages of a case-based approach to this project? One difficulty of time-series approaches as practised in sociology (and panel regression in particular) is an absence of consideration of the fit between empirical specifications of dynamic models, and theories guiding model fit and interpretation. Some debate exists in the political science literature (Keele and De Boef 2004; Keele and Kelly 2006; De Boef and Keele 2008), which deals not only with technicalities of model specification, but with the "assumptions they impose on the dynamics that govern how $\mathrm{x}$ and the errors impact $\mathrm{y}$ " (Beck and Katz 2009, p. 7). For case-based analysts, this often manifests as a concern not only to elaborate the "net impact" of individual causes, but to explore the causal conditions under which outcomes occur (Schneider and Wagemann 2012, p. 86; Vis 2012, p. 169).

The causal logic of QCA is thus equifinal, where multiple combinations of causal conditions can produce the same result (Schneider and Wagemann 2012). Regression is often seen as less capable of dealing with equifinality owing to the issues with interpretation, collinearity, and degrees of freedom in higher-order interaction terms in medium- $N$ dataset (Vis 2012, p. 173; Thiem et al. 2016). QCA treats such causal conditions (variables), in terms of their necessity or sufficiency to bring about an outcome. This approach to causation is difficult in a panel context, as reporting does not typically go beyond the net contribution of individual variables, without placing excessive demands on model specification and assumptions (Schneider and Wagemann 2012, p. 87).

Does this acknowledgement help us advance the longitudinal study of inequality and regulation? We know that the institutional structures of states, and their orientations to redistribution, play a critical role in determining levels of inequality. These causal channels are not uniform, and they abound with contradictions. How, for example, can a state such as Denmark sustain high levels of financial sector productivity whilst maintaining strong redistribution and low inequality? Are retrenchment, deunionization, and deregulation necessary preconditions of top income growth? This scope for causal complexity operates not only in cross-section, but over time, yet the causal logic of configurational methods is fundamentally different. A longitudinal QCA thus allows us to explore both the empirical structure of policy regimes in different epochs, 
and to assess the causal necessity of the various institutional conditions ad combinations.

\section{Data and Method}

\subsection{Rationale for Repeated Moving Average Cross-Section Design}

The study data comprises a set of three-year moving averages derived from a larger panel dataset of OECD countries running from 1975 to 2005. Owing both to the volatility of certain key measures, and the difficulty of faithfully representing the longitudinal structure of the data at discrete time points, I opted for a set of repeated cross-sections comprised of moving averages, incorporating phases from the beginning, mid-point, and end of the available data (1) 1975-1977, (2) 1989-1991, and (3) 2003-2005. Calibrating measures at each time point accounts for structural breaks and trends in the time series. Although some authors attempt to incorporate longitudinal design into QCA, they arguably do not overcome the core issue of representing the changing configurations of cases, their mobility within and between causal conditions and set memberships, and their location within the overall property space relative to other cases at given points in time (Hino 2009). Fixedeffects QCA attempts to address this by setting case-specific calibration criteria using all data points from within an individual case (country) over time for each causal condition (variable). In doing so, it focuses more clearly on variations within units over time, but discards variation between units. As such, the variation within each case is treated as a unique instance relative to others. As our interest is to tease out the causal factors which mitigate rising income concentration, however, retaining information on how cases are located relative to each other is central.

The defining rationale for a configurational approach is its theoretical fit with the datagenerating process - the presence of a defined theory of longitudinal variation, and a causal narrative linking policies and institutions (regulation, finance, and collective power resources) to outcomes (inequality). As such, it is the empirical structure of these epochs, as derived from the cases themselves, which is of primary interest - what conjunctions of condition are observed within time periods, and how they change. This is a fundamental departure from the logic of panel regression analysis which views significant historical epochs as conditions to be controlled through, for example, structural breaks or trend dummies, or the purging of unit heterogeneity through fixed effects. The causal logic of such an approach through regression is unifinal, and based on interaction with additive partial effects, rather than conjunction (Schneider and Wagemann 2012, p. 86; Thiem et al. 2016).

\subsection{Data and Measurements}

The share of total income accruing to the top 1 per cent is our outcome variable. Considering the qualitatively specific and historically variable pathways to top income growth suggested above, the top incomes variable captures a unique aspect of inequality under finance-driven capitalism. The World Wealth and Inequality Database combines taxation-based income estimates with standardized gross income and population totals, enhancing cross-national comparability (Atkinson and Piketty 2007; Atkinson et al. 2010). The time coverage of the data is limited by the availability of suitable measures 
of financial regulation and financialization. The most complete set of measures capturing individual components of financial regulation is that of Abiad et al. (2008) which runs until 2005. This set contains information on specific regulatory measures such as the extent of banking sector supervision, sectoral entry barriers, and financial controls.

Based on the foregoing review of literature, the classic causal combination, or set of variables which defines the property space of finance-driven inequality, consists of measures of government consumption as a share of GDP from Penn World Table (Heston et al. 2012), union density (Visser 2013), financial globalization measured as the share of external assets and liabilities as a percentage of GDP, and Abiad et al.'s (2008) financial reform index, with greater scores indicating greater extents of banking sector liberalization. Government consumption and union density are key measures of distributive capacity amongst labour and government, and consistently feature in studies of top income shares (Kus 2012; Volscho and Kelly 2012; Stockhammer 2013; Flaherty 2015). Our financialization variables are of direct relevance to regulation, and hence, national or trans-national policy. Abiad's is an index which takes account of such policy variation in its construction - for example, whether a country has adopted Basle capital adequacy standards (international), or ease of foreign entry to domestic markets (national). Financial globalization was observed as an especially strong predictor of inequality (Flaherty 2015), and in turn captures the relative empowerment of mobile capital under financial deregulation, as well as the diversification of within-firm income streams and, especially, pre-crisis exposure of national economies to volatile financial markets.

The final dataset captures a mix of liberal, corporatist, Antipodean, and social-democratic welfare states, liberal, coordinated market, and Asian economies. Nine missing data points (Korean income, 1989-1991, Spanish income, 1975-1977; Portuguese unionization, 1975-1977) were imputed with a third-order polynomial. Financial globalization (finglob) was logged prior to calibration, but for ease of interpretation, the original measure is reported in all tables. All subsequent output was derived using the transformed version. Appendix Table A1 provides summary statistics by country, and for the outcome variable (top1), the coefficient of a trend dummy in a linear panel regression is provided (top1 change) This gives an indication of the direction of change across the pool of cases. Full details regarding labels, measures, and sources are provided in Table 1, which also summarizes the theoretical relevance of the individual measures as parameters of the property space.

A note of caution is required on the method of calibration used in this paper. Calibration by establishing relevant anchor points for various degrees of set membership is an inherent benefit of fsQCA. To justify calibration, the theoretical relevance of the anchor points must typically be argued. This study uses statistical rather than theoretical criteria, and direct calibration to calibrate set membership, a technique often at odds with the wider case-based literature. The data in this study are limited by several factors suitable financialization data to use as policy indicators, the time coverage of such data, and, primarily, the availability of top 1 per cent income data from the World Wealth and Inequality Database. Sets in this study were formed by direct calibration. This involved centring variables, adopting minimum and maximum scores as anchors for non-membership and full membership, and 0 as the point of maximum ambiguity. The procedure was repeated for all three waves, yielding unique calibration for each, within each time frame. Table 2 below lists set membership scores for each case on each condition. 


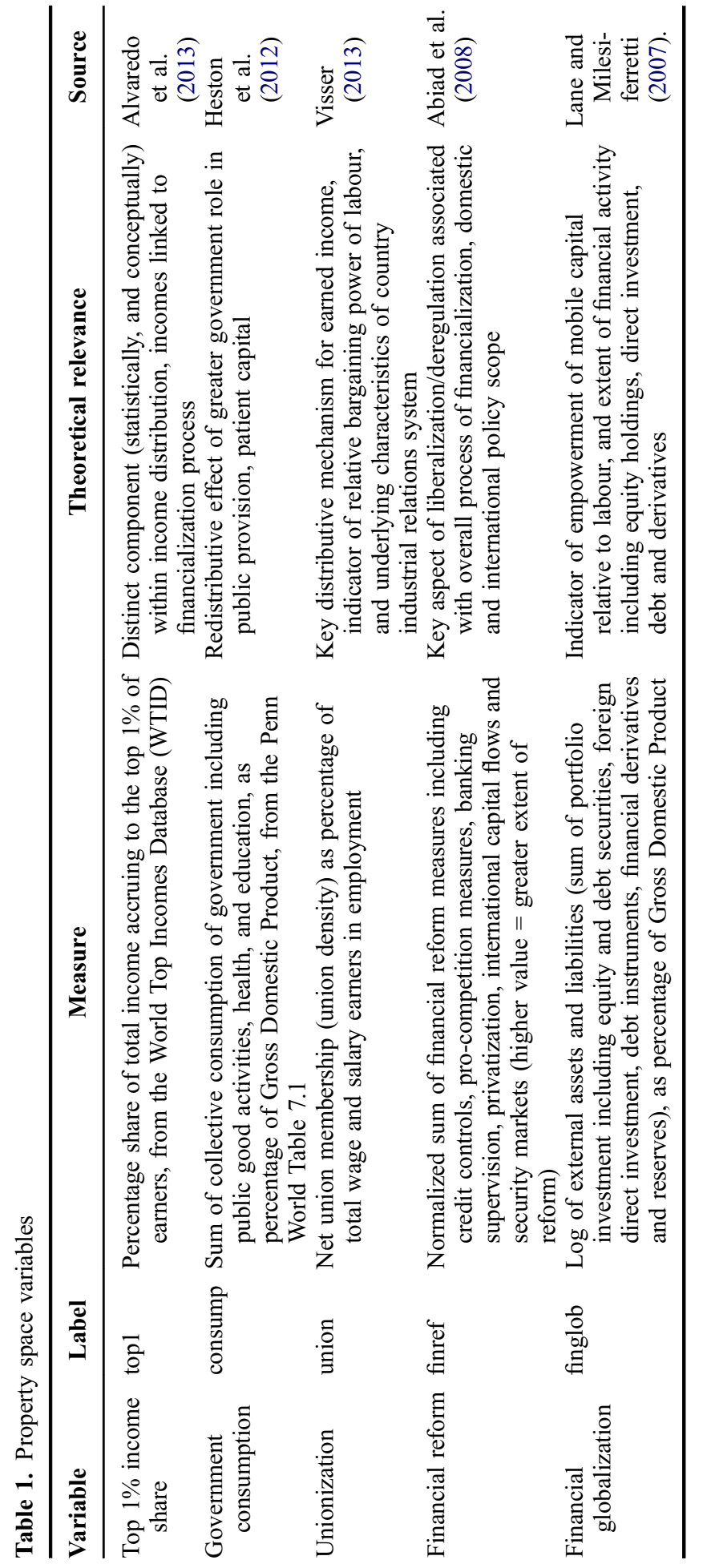




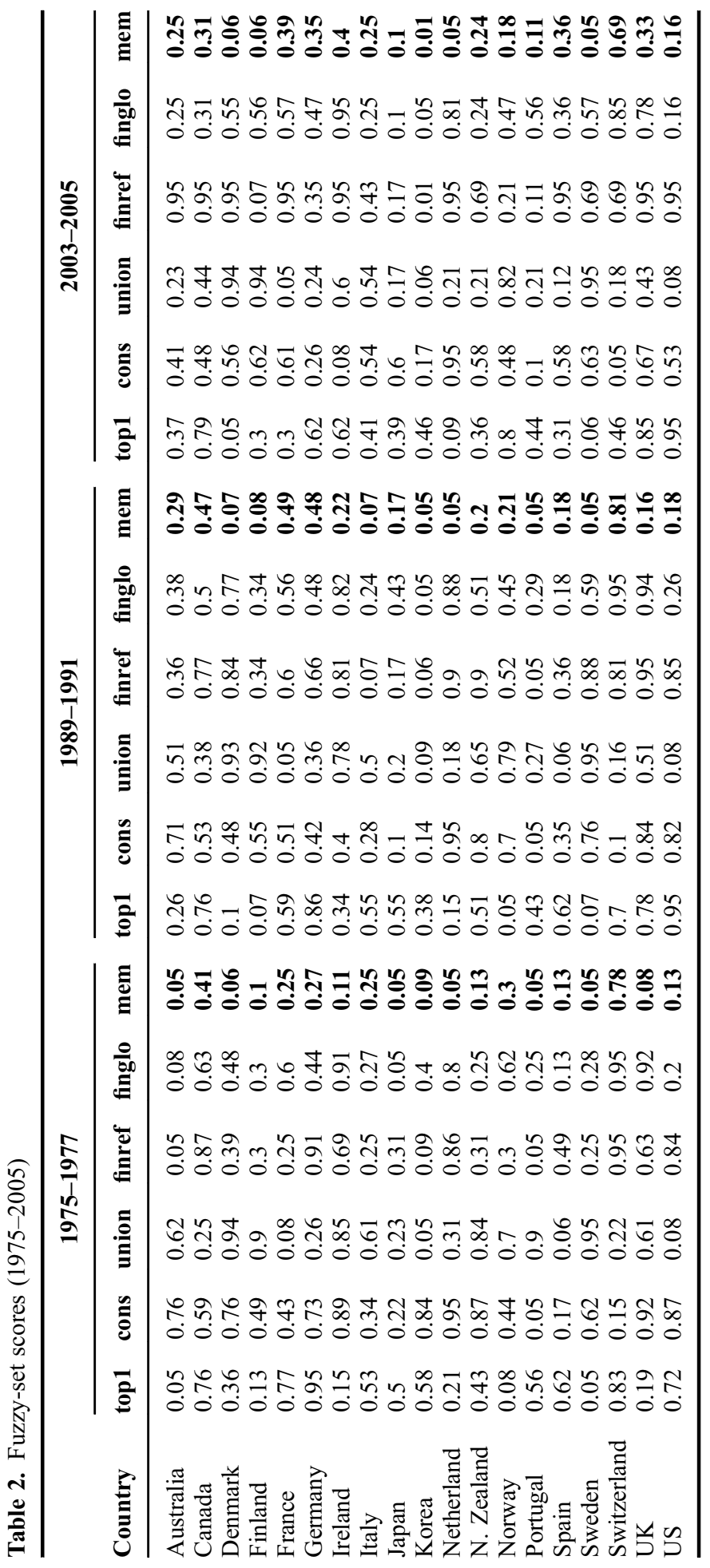


Given the method of calibration used, some justification is required. Pennings (2005, p. 325) suggests in his study that, when dealing with a full set of OECD cases, the data be viewed as constituting a population in the absence of external reference points $(2005, \mathrm{p}$. 325). These criteria are not met by this study, owing to availability issues above, but this should not limit the utility of its findings. First, the conceptual coherence of the OECD is arbitrary relative to more defined conceptual schemes (such as worlds of welfare capitalism for example, where specific measures constitute criteria for inclusion. One could argue that the dataset in this study comprises a representative mix of cases - high and low inequality, more and less financialized, representatives from key worlds of capitalism - although it is insufficient to establish a conceptual basis for "population". The key issue with direct calibration is that movement of cases in and out of the dataset will alter the original membership scores. However, any anchor point set for the various finance measures in this data would be purely arbitrary - especially so in the case of financialization data which is very much an active area of research.

As this is an exploratory study, I pay attention to the location of cases within the property space, relative to each other, whilst bearing in mind that the addition of cases may alter scores using these calibration criteria, since the method is data-dependent (Verkuilen 2005). Any arguments to causal necessity and sufficiency should be taken as tentative, and subject to modification if more cases become available. The full data are provided as Appendix Table A2 for replication and reinterpretation - and I proceed on the assumption that direct calibration from standardization, and full publication of the original data, is the most objective means of overcoming this issue. As noted above, there is an insufficient basis for establishing this pool of cases as a population, and as such, any causal inference should be limited to the pool of cases used in this paper.

\section{Results}

In the notation of sets, we use $\sim$ to denote the absence of a condition. The classic causal combination as derived from the literature above can now be stated as: low levels of government consumption, low levels of unionization, high levels of financial deregulation, and high levels of financial globalization. In fuzzy logic, the interpretation of "absence" of a condition is not zero, but as "more out of" the set of cases scoring high on the condition in question. The resulting ideal-type causal combination is thus: ${ }^{1}$

$\sim$ con * $\sim$ union * finref * finglo

Membership scores were assigned to each case following the procedure laid out by Ragin (2008), by which a case's degree of membership in a causal combination is given by the lowest value of the conditions used (in this case, the lowest score on the sets $\sim$ con * union * finref* finglo). Working from this "classic" causal combination, it is possible to assess its causal sufficiency by plotting its combination membership scores against membership scores of the outcome. Causal sufficiency for a given combination is indicated when scores on the outcome are higher than the cause on a bivariate plot of both score sets (i.e. in an ideal case of sufficiency, when membership of the combination is high, so too are its scores on inequality). We can use this approach to begin exploring the fit between these regression-derived conditions in a case-based context. The following discussion focuses not only on the reduced solutions (more of which to follow), but especially on the scores assigned to individual cases on each condition, as provided in Table 2. 
Figure 2. Classic combination membership and outcome score consistency, 03-05

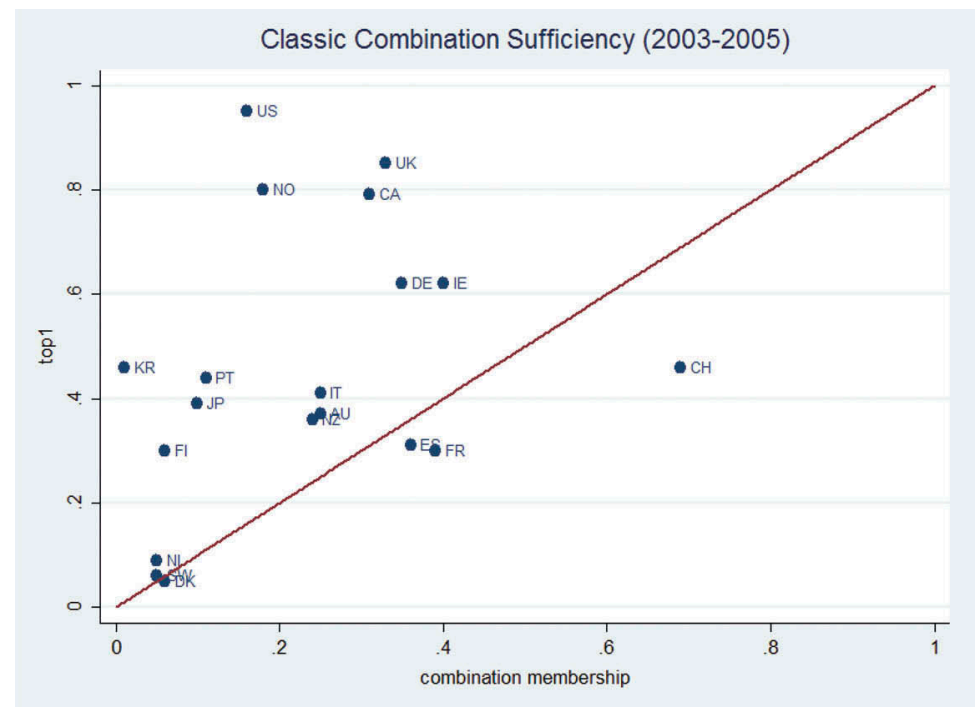

Taking the most recent wave of data (2003-2005), Figure 2 shows a Nordic cluster of "low combination * low inequality" toward the origin, and a less coherent cluster of Anglo-Saxon nations toward the top-left quadrant. The US, UK, Canada, and Norway reflect both high degrees of top income inequality, and highly deregulated financial markets. Comparatively low levels of financial globalization in the US places the US low in its membership, but together they demonstrate generally high levels of financial deregulation (finref), coupled with lower degrees of unionization ( union) and government consumption ( $\sim$ con). Norway gives an early indication of divergent causal pathways, by combining high degrees of unionization with both low regulation, and high inequality, as an exception amongst the Ghent countries (Ebbinghaus and Manow 2001). Compared to a liberal exemplary such as the US, this suggests that financial deregulation is by itself insufficient for high inequality.

As stated above, a case is deemed consistent if its score on the causal combination is greater than its score on the outcome. Intuitively, when attempting to assess the utility of a causal combination, cases where membership is high but their score on the outcome is low (i.e. below the diagonal) are deemed inconsistent. France, Spain, but especially Switzerland, contradict the causal pattern by strongly fitting the causal criteria but showing lower membership of the inequality set (by the causal logic of the classic combination, we should expect high degrees of membership on these cases). Those cases demonstrating membership of the outcome greater than their score on combination membership thus contradict the argument for causal necessity as their presence on the outcome is independent of their conformity to the causal mix (Schneider and Wagemann 2012, p. 75).

This suggestion may be formalized by measuring the consistency of the results. In Figure 2, for example, we assign these cases the outcome score instead, and divide this new figure by the total of original membership scores in the set. An ideal solution with perfect consistency (i.e. no 
deviant cases) would score closer to 1. Coverage is obtained by summing the consistent (nondeviant) membership scores, and dividing by the sum of outcome membership. The distinction between coverage and consistency is important, as although the causal combination may score high on consistency, the proportion of cases conforming to the causal path may be low, reducing the weight of evidence for the combination as causally sufficient - in which case further exploration of causal combinations case by case may be warranted. The solution measures consistent at 0.913 , but its coverage scores 0.460 . This solution thus may not be sufficient alone to account for the causal paths to inequality.

The picture is complicated when we consider the placement of cases on the plot, where no cases record both membership of the outcome and conjunction. This suggests that for the most recent data period, the classic combination does a poor job of explaining top income inequality. This pattern holds for 1975-1977 and 1989-1991, where only Switzerland fits the causal argument (see Appendix Figures A1 and A2 for these graphs). Despite the evident insufficiency of the classic causal argument alone, its absence is important, and to be explained - why, despite the weight of evidence in the literature, is this pathway not observed empirically?

\subsection{Causal Complexity Over Time - Causal Pathways to Finance-Driven Inequality}

We may explore this further by examining summaries of the classic solution over the three waves of data. Consistency and coverage scores across waves (see Appendix Table A3) suggest that (1) the conformity of the "classic" causal conditions of inequality becomes more generalized across cases over time, but (2) in light of the stable consistency and modest coverage, the potential remains for greater causal complexity than indicated by the classic combination of $\sim$ con * union * finref * finglo. The table of fuzzy-set scores provides little evidence for causal necessity amongst any of the causal conditions. Utilizing the subset principle of fuzzy-set analysis, there are no instances across any of the conditions over all three waves where single conditions are necessary to produce high inequality (i.e. there are no instances in which the outcome is a clear subset of the individual causal conditions). Consistent with previous work on welfare state expenditure, this is largely to be expected as it is unlikely that any single factor is necessarily connected to high inequality (Pennings 2005, p. 326). The increase in coverage scores on the classic solution may indicate modest increase in its generalizability over time.

From this basic preliminary analysis, we can begin to deconstruct causal complexity in greater detail, by exploring the presence of additional causal combinations in different eras by means of a truth table, and by subsequently considering the relative locations of cases in the various combinations. Table 3 presents an assessment of causal diversity beyond the combination assessed thus far. It condenses the results of three truth tables (see Appendix Tables A3 and A4), one for each wave of data, into a set of empirically relevant causal combinations derived from the data. As such, each tabulated causal combination exhibits a consistency and coverage score, and a complex solution (discussed below). Whilst these do not represent all possible observed causal combinations, they constitute the most consistent, based on the standard procedure of discarding those combinations with low empirical occurrence as remainders.

The truth table was constructed using a cut-off number of two (those combinations with one or less occurrence), and a consistency threshold of 0.80 , above which causal combinations returned in the truth table were retained for further analysis. The decision to choose a cut-off point is important, as it involves making an explicit claim that causal solutions evident on only one case are "too unique". Whilst this is often a difficult decision to justify in the context of a panel design, it is necessary to achieve a suitable balance between reductionism and complexity. 
Table 3. Causal solutions from fuzzy-set truth table analysis (number $>1$, consistency $>0.79$ )

\begin{tabular}{|c|c|c|c|}
\hline & 1975-1977 & 1989-1991 & 2003-2005 \\
\hline $\begin{array}{l}\text { Causal combinations with } \\
\text { highest consistency scores }\end{array}$ & $\begin{array}{c}\text { con * } \text { union * finref } \\
* \sim \text { finglo } \\
\sim \text { con } * \sim \text { union } * \\
\sim \text { finref } * \sim \text { finglo }\end{array}$ & 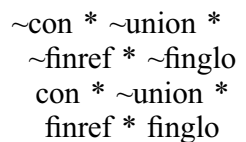 & $\begin{array}{c}\sim \text { con * } \sim \text { union } * \\
\text { finref } * \sim \text { finglo } \\
\sim \text { con } * \sim \text { union } * \\
\sim \text { finref } * \sim \text { finglo }\end{array}$ \\
\hline Consistency score & $0.923,0.840$ & $0.819,0.808$ & $0.891,0.889$ \\
\hline Complex solution & $\begin{array}{l}\text { con* } \\
\sim \text { union* } \\
\text { finref* } \\
\sim \text { finglo* }\end{array}$ & $\begin{array}{l}\sim \text { con* } \\
\sim \text { union* } \\
\sim \text { finref* } \\
\sim \text { finglo }\end{array}$ & $\begin{array}{l}\sim \text { con* } \\
\sim \text { union* } \\
\sim \text { finglo* }\end{array}$ \\
\hline Complex solution consistency & 0.923 & 0.820 & 0.854 \\
\hline Complex solution coverage & 0.425 & 0.519 & 0.622 \\
\hline
\end{tabular}

These results are simplified further using the complex solution procedure (Ragin 2008, p. 174). This process utilizes the results of the truth table to reduce the set of observed causal combinations into simpler solutions. This is achieved by removing those conditions which are present on all combinations (and therefore irrelevant as independent causal conditions, as they are necessary to observing the outcome). The complex solution is here preferred as it requires no assumptions on the behaviours of conditions to be entered by the user-simplifying instead from all empirical observations in the dataset. Following the procedure adopted above, plots of membership scores on the complex solution $(\mathrm{X})$ against the outcome $(\mathrm{Y})$ are provided to test the relative consistency of the alternative combination as a causal path to high inequality (see Figures 3, 4, and 5).

Of note is the continuing presence of $\sim$ union in the solutions for all three waves, suggesting a power resources argument may be central to accounting for top income growth. Its role appears less ambiguous than that of the other conditions, and its timing coincides with the classic "structural break" of the post-oil crisis era in collective labour, where workers' shares of productivity began to decline, assisted by technology-driven skill premiums, and state/corporate antagonism toward the labour movement (ILO 2013). The effect of deunionization is that top income growth accelerated as wage equalization declined under weakening unions, and where bargaining power in new technology-based sectors resided not in collective solidarity, but with the capacity to leverage scarce technical skills for greater returns.

In short, as service and knowledge-work overtook industrial employment, bargaining power became "individualized". Such is the problematic skill-biased technological change argument (Atkinson 2009), but it reflects deeper structural shifts in compensation and pay dynamics. Piketty remarked on the impact of reduced top income taxation as a measure which opened space for top earners to bargain for greater pay without the risk of losing gains to the exchequer. The issuing of stocks as components of compensation, and the shifting of the tax away from the top, are themselves policies which are part of the process of financialization - tying top incomes to the market performance of firms, and eroding regulations designed to keep such systems in check (Thompson 2013). In generalizing these findings, however, some cautions are warranted. First, the issue of sample selectivity as discussed above must be kept in mind, as the calibration (and hence solutions) are data-dependent. Second, limited diversity is evident in the solutions presented in the truth tables (see Appendix Table A4), where 


\section{E. Flaherty}

Figure 3. Complex solution membership and outcome score consistency (1975-1977)

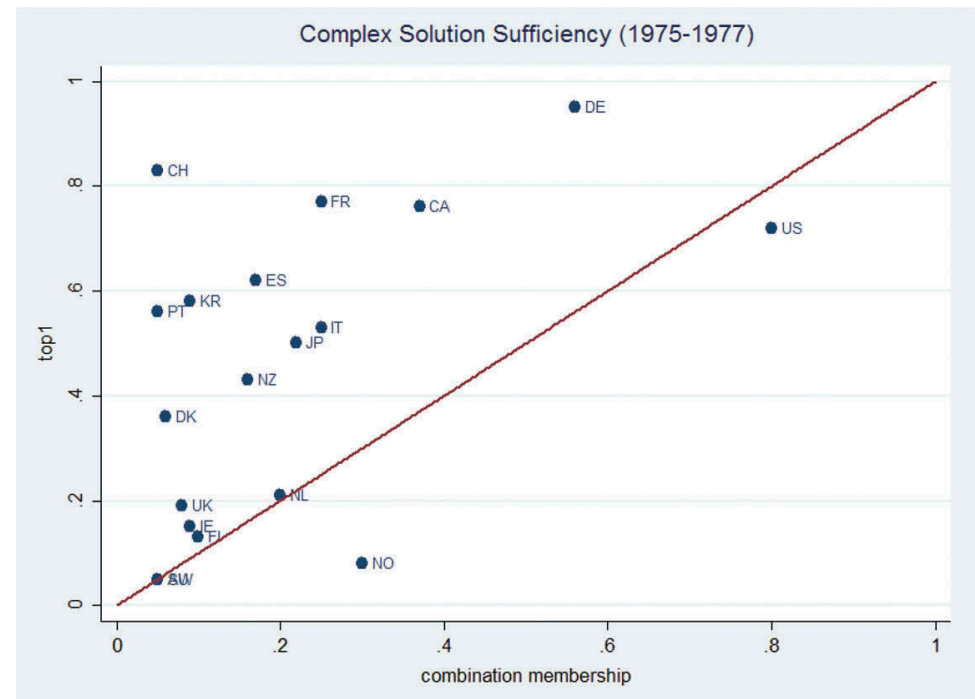

Figure 4. Complex solution membership and outcome score consistency (1989-1991)

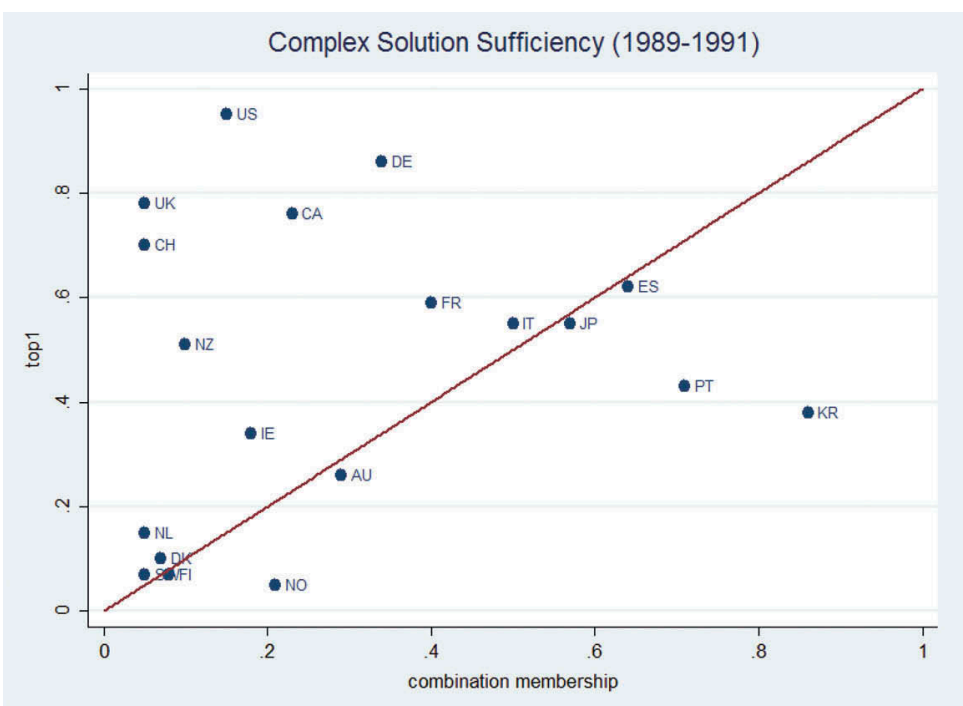


Figure 5. Complex solution membership and outcome score consistency (2003-2005)

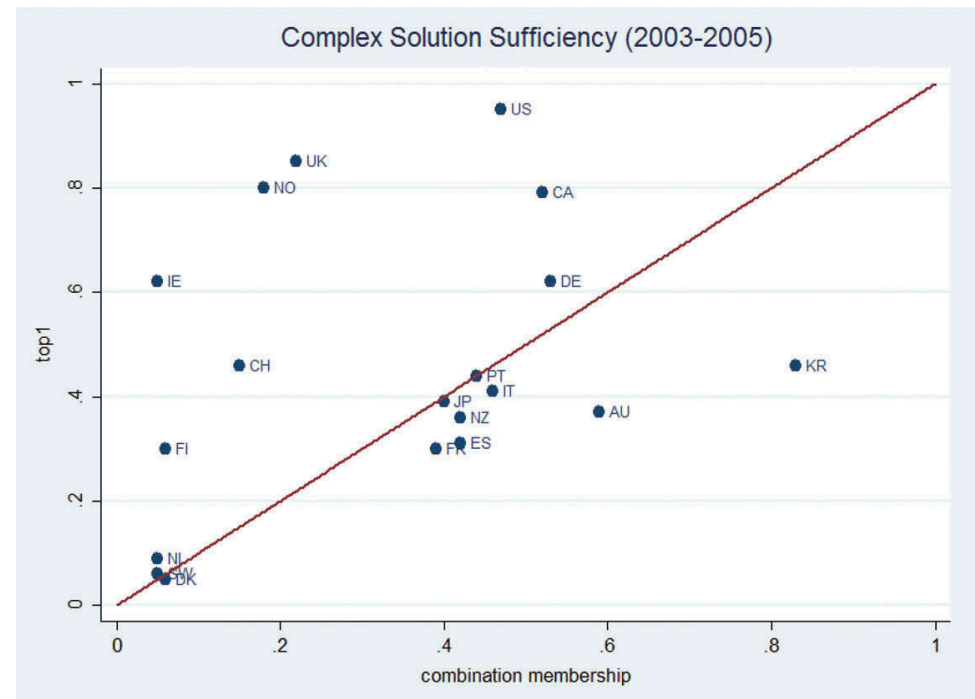

no empirical instances of several possible combinations are observed. The solution plots (Figures 3-5) also show few empirical instances of the conjunction and outcome (particularly so in 1975-1977). As such, we conclude by considering diversity across key cases, in an attempt to balance this dual goal of parsimony via the solution, and complexity via the cases (Ragin 2008, pp. 148-149).

\subsection{Diversity Across Cases}

Returning to the level of cases and configurations, we find that in the 1970s, deregulation and deunionization appear prominent conditions of top income growth, but by the 1990s and 2000s, regulation and financial globalization become irrelevant. Low consumption became central to the causal path in 1989-1991, consistent with a general shift amongst capitalist democracies in the sample from supply- to demand-facing models of investment and public funding. Denmark records the only decline of the sample of cases included in this study - reflecting its resilience to other forms of inequality such as its stable rate of change in labour's share of national product (Flaherty and Ó Riain 2015). This despite its higher rate of financial sector productivity draws attention to the causal factors underpinning its seemingly higher capacity for redistribution. The case presents an interesting contradiction - Denmark records a productivity rate (per capita gross values added) in its financial sector which outstripped that of manufacturing - and indeed all other economic sectors - throughout most of the 2000s, surpassing that of Ireland which is typically held as a model of finance-based economic growth (Ó Riain 2012, 2014; Flaherty and Ó Riain 2013, p. 66).

In the financialization "exemplar" of the US, 41 per cent of the world's millionaires are found, and high levels of shareholding and debt set it almost eight times greater than its nearest 
contender (China) in terms of ultra-high-net-worth individuals (Credit Suisse 2014, p. 46). The contrast of causal paths bears closer inspection: both retain respective membership/non-membership of their outcome sets, but whilst Denmark enters the set of reformed countries in its second wave, it retains its membership of unionized nations - and stronger financial globalization. As such, it contradicts the "either/or" logic - and the dominant narrative of neoliberal institutionalism - as financialization is neither predicated on an erosion of collective power resources, nor predictive of high inequality following from deregulation and financial globalization.

There are also contradictory cases in the causal mix where financial globalization is implicated - it remains consistently relevant to the UK, which joins the set of high-inequality countries in 1989-1991, yet is absent in the US. Conversely, Switzerland exits the set of high inequality nations in 2003-2005, despite remaining in the set of financially globalized nations. Financial globalization thus appears irrelevant to the passage of a country to high inequality. The UK-US comparison is perhaps most illuminating in terms of the proximate "causes" of the financial crisis, with outward-looking inter-agency investment playing the greater role in the UK, relative to the endogenous inter-agency securitization lending practices in the US financial system. Both pathways, inevitably, lead to similar avenues for top income accumulation. Finland reinforces the ambiguity of regulation in the "classic model", with low levels of reform, yet similar non-membership of the high-inequality set.

How might we account for the irrelevance of regulation in the causal mix for 2003-2005 (the complex solution)? Furthermore, what accounts for its presence in 1975-1977? The comparative capitalisms literature often distinguishes between "patient" and "financial" capital channels as the basis for capital accumulation. The standard argument would suggest that under tightly regulated capital markets, and with a notional separation of commercial and investment banking, that "patient" capital constituted a necessary condition of top-income-set membership in the 1970s. As deregulation continued apace during the 1980s and 1990s, deregulation becomes ever more central to the causal mix driving top-income-set-membership - before becoming irrelevant in the immediate pre-crisis era. This is consistent with panel evidence from the immediate crisis era which shows a smaller impact for regulation on top incomes (Flaherty 2015).

\section{Conclusion}

Is financialization therefore a sufficient condition of high inequality? Evidence from the analysis is weak, even if we adopt a high threshold of ambiguity. ${ }^{2}$ The generalizability of the classic causal combination has precedent in the wider inequality literature, especially in work on Europe where common policy frameworks - EMU for example, or Basel compliance (Guttman 2008) - may have accelerated processes of retrenchment (Beckfield 2006, 2009). The literature on labour's share also identifies institutional convergence, in the form of product and labour market deregulation, as a key inequality stressor - although the "contagion mechanism" is more nebulous than centralized European monetary policy, instead often attributed to a general decline in the collective power of labour worldwide. Why, therefore, does this argument appear not to hold when examined across cases? It is possible that manifest regulation may play the lesser role, and this is certainly plausible when considering the development of "shadow" banking sectors in countries such as Ireland (in developer-led property lending) and the US (with subprime mortgage markets). Their role in driving top incomes is well established, and potentially independent of formal regulation. 
The consistent solutions derived above appear less compatible with the evidence - as seen from the positioning of ambiguous cases to the lower half of the scatterplots in Figures 3-5, and the absence of any empirical instances of both classic combination membership, and high inequality (Switzerland aside). This may indicate a fragmentation of the factors of financedriven inequality, whereby context becomes the greater determinant of whether a country experiences high inequality as a result. Similarly, the solution convergence and coverage score may reflect a gradual erosion of the applicability of the classic model. Overall, the evidence revealed by this exercise suggests the unifinal narrative of finance-driven inequality is more fragmented than regression-based analyses may suggest. Notwithstanding the evidence furnished by panel studies, mechanisms must be theorized through the lens of cases, as stressors are ultimately filtered through national contexts. These findings potentially add empirical clarity to macro-models of inequality such as that of Piketty's (2014) model which emphasizes an "excess of capital returns over base economic growth" as a mechanism for rising top inequality. If such models can be accused of suffering from an under-appreciation of context, strategizing for redistribution can be assisted by exercises such as this. Even those frameworks which attempt to ground financialization's mechanisms at the level of the firm and workplace (Thompson 2013) tend to reproduce narratives of neoliberal institutionalism, which emphasize either the Anglo-Saxon, or liberal market experience. Our results thus contradict this dominant narrative, in line with Thelen's critique of decontextualized liberalization processes (2014).

What of the political project of redistribution? The presence of $\sim$ con and $\sim$ union in the various solutions is important here. Whilst a case-by-case analysis shows departures from the classic formula of inequality under financialization, a consistent role for institutional resources linked to redistribution (government spending and unionization) is found. Whilst the Anglo-Saxon literature asserts the relevance of a power resources argument, the reality of implementation is more complex. Whilst the regression-based literature is emphatic on the net effect of financebased stressors of equality, the possibility of reverse-engineering policy solutions based on panel evidence alone is clearly short-sighted. Whilst proposed measures such as financial transaction taxes would go some way toward mitigating the tendencies of financialization toward greater top income growth, the causal pathways to high inequality are not necessarily uniform. Whilst power resources appear central to the mix of conditions which could - taking a probabilistic interpretation of our findings - offset top income growth, they interact in different ways with different conditions to produce divergent outcomes. The question is whether the sacrificing of parsimony inherent in a QCA approach is of benefit to processes of policy strategizing which typically lean on macro-level arguments about the effects of different variables.

Whereas authors such as Jayadev (2007) and Stockhammer (2013) assert both the damaging effects of deregulation on the distribution of income (factor and personal), as well as the greater effect of financialization relative to other stressors such as globalization and technology, the evidence here reinforces the centrality of workers and public power resources to potential redistribution. Although we have a sound empirical basis for establishing a common experience of financialization across advanced capitalist democracies, conventional forms of social protection still matter. The continuing relevance of institutional diversity is reminiscent of Boyer's configurational exercise, which noted underlying diversity in domestic growth capacity between social democracies and deregulated market economies (Boyer 2004). Deferring to SSA theory, its key conceptual point is that assuming the existence of basic systemic-wide properties - such as a fundamental antagonism between capital and labour, or the centrality of inequality to capitalism - need not lapse into crude structuralism (Jessop 2001, 2013). There is a clear pathway to agency 
and diversity in this general narrative which resonates with Polanyi's concept of the "double movement", where systemic contradictions open space for a variety of possible pathways to inequality depending on national contexts (Dale 2010). In short, as Polanyi emphasized the variety of possible social compacts emerging from fundamental social tensions, so too should we expect to find variation in the contexts and drivers of inequality as financialization enacts its structural changes in diverse ways - to the benefit of some, and detriment of others.

\section{Notes}

1. Scores for $\sim$ con and $\sim$ union are thus derived using the negation rule, where degree of "non-membership" (i.e. degree of membership in the non-unionized set), is given by: $\sim=1$-[set membership score].

2. The results of this exercise run contrary to expectations, particularly in context of the wider financialization and comparative inequality literatures. The negative results are surprising, but the presence of diversity in the various configurations of membership scores is not (see Roberts and Kwon 2017 for a discussion of varieties of capitalism and finance-driven inequality). Alternative calibration strategies could be explored in future work, but there is currently little consensus in the literature, or intuitive anchors in the various distributions, from which to construct meaningful membership thresholds.

\section{References}

Abiad, A., Detragiache, E. and Tressel, T., 2008, A new database of financial reforms. IMF Working Paper WP/ 08/266. International Monetary Fund Institute and Research Department. doi:10.1057/imfsp.2009.23

Alvaredo, F., Atkinson, A. B., Piketty, T. and Saez, E., 2013, The top 1 percent in international and historical perspective. Journal of Economic Perspectives, 27, pp. 3-20. doi:10.1257/jep.27.3.3

Atkinson, A. B., 2009, Factor shares: The principal problem of political economy? Oxford Review of Political Economy, 25, pp. 3-16. doi:10.1093/oxrep/grp007

Atkinson, A. B., Piketty, T. and Saez, E., 2010, Top incomes in the long run of history, in: A. B. Atkinson and T. Piketty (Eds) Top Incomes: A Global Perspective (Oxford: Oxford University Press), pp. 664-760.

Atkinson, T. and Piketty, T. (Eds), 2007, Top Incomes over the Twentieth Century: A Contrast between Continental European and English-Speaking Countries (Oxford: Oxford University Press).

Beck, N. and Katz, J., 2009, Modeling dynamics in time series cross-section political economy data. California Institute of Technology Social Science Working Paper \#1304

Becker, J. and Jager, J., 2010, Integration in crisis: A regulationist perspective on the interaction of European varieties of capitalism. Competition and Change, 16, pp. 169-187. doi:10.1179/1024529412Z.00000000012

Beckfield, J., 2006, European integration and income inequality. American Journal of Sociology, 71, pp. 964985. doi:10.1177/000312240607100605

Beckfield, J., 2009, Remapping inequality in Europe: The net effect of regional integration on total income inequality in the European Union. International Journal of Comparative Sociology, 50, pp. 486-509. doi:10.1177/0020715209339282

Boyer, R., 2004, New growth regimes, but still institutional diversity. Socio-Economic Review, 2, pp. 1-32. doi:10.1093/soceco/2.1.1

Bruff, I. and Horn, L., 2010, Varieties of capitalism in crisis? Competition and Change, 16, pp. 161-168. doi:10.1179/1024529412Z.00000000011

Byrne, D., 1998, Complexity Theory and the Social Sciences (London: Routledge).

Credit Suisse, 2014, Global Wealth Report. (Switzerland: Credit Suisse Investment Banking). https://publica tions.credit-suisse.com/tasks/render/file/?fileID=60931FDE-A2D2-F568-B041B58C5EA591A4

Dale, G., 2010, Social democracy, embeddedness and decommodification: On the conceptual innovations and intellectual affiliations of Karl Polanyi. New Political Economy, 15, pp. 369-393. doi:10.1080/ 13563460903290920

De Boef, S. and Keele, L., 2008, Taking time seriously. American Journal of Political Science, 52(1), pp. 184200. doi:10.1111/j.1540-5907.2007.00307.x 
Ebbinghaus, B. and Manow, P., 2001, Introduction: Studying varieties of welfare capitalism, in: B. Ebbinghaus and P. Manow (Eds) Comparing Welfare Capitalism: social Policy and Political Economy in Europe, Japan and the USA (London: Routledge), pp. 145-167.

Epstein, G. and Power, D., 2003, Rentier incomes and financial crises: An empirical examination of the trends and cycles in some OECD countries. Canadian Journal of Development, 24, pp. 229-248. doi:10.1080/ 02255189.2003 .9668914

Flaherty, E., 2015, Top incomes under finance-driven capitalism: 1990-2010: Power resources and regulatory orders. Socio-Economic Review, 13(3), pp. 417-447. doi:10.1093/ser/mwv011

Flaherty, E. and Ó Riain, S., 2013, Labour's share of national income in Ireland and Denmark: Similar trends, different dynamics. National Institute for Regional and Spatial Analysis Working Paper No. 70. (Maynooth: National Institute for Regional and Spatial Analysis).

Flaherty, E. and Ó Riain, S., 2015, The variety of polanyian double movements in Europe's capitalisms, in: S. Ó Riain, F. Behling, R. Ciccia and F. Flaherty (Eds) The Changing Worlds and Workplaces of Capitalism (London: Palgrave Macmillan), pp. 38-57.

Foster, J. B. and Holleman, H., 2010, The financial power elite. Monthly Review, 62, pp. 1-19.

Grossman, E. and Woll, C., 2014, Saving the banks: The political economy of bailouts. Comparative Political Studies, 47, pp. 574-600. doi:10.1177/0010414013488540

Guttman, R., 2008, A primer on finance-led capitalism and its crisis. Revue de la Regulation, 3/4, http:// regulation.revues.org/5843. doi:10.4000/regulation.5843

Heston, A., Summers, R. and Bettina, A., 2012, Penn World Table Version 7.1. Centre for International Comparisons of Production, Income, and Prices at the University of Pennsylvania. http://cid.econ.ucdavis. edu/pwt.html

Hino, A., 2009, Time-series QCA: studying temporal change through Boolean analysis. Sociological Theory and Methods, 24(2), pp. 247-265.

International Labour Organization, 2013, Global Wage Report 2012/13: Wages and Equitable Growth. (Geneva: International Labour Office).

Jayadev, A., 2007, Capital account openness and the labour share of income. Cambridge Journal of Economics, 31(3), pp. 423-443. doi:10.1093/cje/bel037

Jessop, B., 2001, State theory, regulation, and autopoiesis: Debates and controversies. Capital and Class, 25, pp. 83-92. doi:10.1080/13563460120060616

Jessop, B., 2013, Revisiting the regulation approach: Critical reflections on the contradictions, dilemmas, fixes and crisis dynamics of growth regimes. Capital and Class, 37, pp. 5-24. doi:10.1177/0309816812472968

Keele, L. and De Boef, S., 2004, Not just for cointegration: Error correction models with stationary data, Working Paper. http://www.nuff.ox.ac.uk/Politics/papers/2005/Keele\%20DeBoef\%20ECM\%20041213.pdf

Keele, L. and Kelly, N., 2006, Dynamic models for dynamic theories: The ins and outs of lagged dependent variables. Political Analysis, 14(2), pp. 186-205. doi:10.1093/pan/mpj006

Kenworthy, L., 2010, Institutions, wealth, and inequality, in: G. Morgan, J. L. Campbell, C. Crouch, O. K. Pedersen and R. Whitley (Eds) The Oxford Handbook of Comparative Institutional Analysis (Oxford: Oxford University Press), pp. 399-420

Kenworthy, L., 2017, Why the surge in income inequality? Contemporary Sociology, 46(1), pp. 1-9. doi:10.1177/0094306116681789

Kim, J. W., Kogut, B. and Yang, J.-S., 2015, Executive compensation, fat cats, and best athletes. American Sociological Review, 80, pp. 299-328. doi:10.1177/0003122415572463

Kotz, D. M., 2003, Neoliberalism and the social structure of accumulation theory of long-run capital accumulation. Review of Radical Political Economics, 35, pp. 263-270. doi:10.1177/0486613403255542

Kristal, T., 2010, Good times, bad times: Postwar labor's share of national incomes in capitalist democracies. American Sociological Review, 75(5), pp. 729-763. doi:10.1177/0003122410382640

Kus, B., 2012, Financialisation and income inequality in OECD nations: 1995-2007. The Economic and Social Review, 43, pp. 477-495.

Kus, B., 2016, Wealth inequality: historical trends and cross-national differences. Sociology Compass, 10(6), pp. 518-529. doi:10.1111/soc4.v10.6

Lane, P. and Milesi-Ferretti, G.M., 2007, The external wealth of nations mark II: Revised and extended estimates of foreign assets and liabilities, 1970-2004. Journal of International Economics, 73, pp. 223-250. doi:10.1016/j.jinteco.2007.02.003

Lin, K. and Tomaskovic-Devey, D., 2013, Financialization and U.S. Income inequality, 1970-2008. American Journal of Sociology, 118, pp. 1284-1329. doi:10.1086/669499 


\section{E. Flaherty}

Mahoney, J. and Thelen, K., 2009, Explaining Institutional Change Ambiguity, Agency, and Power (Cambridge: Cambridge University Press).

McDonough, T., Reich, M. and Kotz, D. M., 2010, Contemporary Capitalism and Its Crisis (Cambridge: Cambridge University Press).

ÓRiain, S., 2012, The crisis of financialisation in Ireland. The Economic and Social Review, 43, pp. 497-533.

Ó Riain, S., 2014, The Rise and Fall of Ireland's Celtic Tiger: liberalism, Boom and Bust (Cambridge: Cambridge University Press).

Pennings, P., 2005, The diversity and causality of welfare state reforms explored with fuzzy-sets. Quality and Quantity, 39, pp. 317-339. doi:10.1007/s11135-004-5006-x

Piketty, T., 2014, Capital in the Twenty-First Century (Cambridge: Harvard University Press).

Ragin, C., 2008, Redesigning Social Inquiry: fuzzy Sets and Beyond (Chicago: University of Chicago Press).

Roberts, A. and Kwon, R., 2017, Finance, inequality and the varieties of capitalism I post-industrial democracies. Socio-Economic Review, 3(1), pp. 511-538. doi:10.1093/ser/mwx021

Rueda, D. and Pontusson, J., 2000, Wage inequality and varieties of capitalism. World Politics, 52, pp. 350-383. doi:10.1017/S0043887100016579

Schneider, C. Q. and Wagemann, C., 2012, Set-Theoretic Methods for the Social Sciences: A Guide to Qualitative Comparative Analysis (Cambridge: Cambridge University Press).

Stockhammer, E., 2004, Financialization and the slowdown of accumulation. Cambridge Journal of Economics, 28, pp. 719-741. doi:10.1093/cje/beh032

Stockhammer, E., 2013, Why have wage shares fallen? A panel analysis of the determinants of functional income distribution. International Labour Office, Conditions of Work and Employment Series. http://ilo.org/wcmsp5/ groups/public/—ed_protect/—protrav/_travail/documents/publication/wcms_202352.pdf

Tabb, W. K., 2010, Financialization in the contemporary social structure of accumulation, in: T. McDonough, M. Reich and D. M. Kotz (Eds) Contemporary Capitalism and Its Crises (Cambridge: Cambridge University Press), pp. 145-167.

Thelen, K., 2012, Varieties of Capitalism: trajectories of Liberalization and the New Politics of Social Solidarity (Florence: European University Institute).

Thelen, K., 2014, Varieties of Liberalization and the New Politics of Social Solidarity (Cambridge: Cambridge University Press).

Thiem, A., Baumgartner, M. and Bol, D., 2016, Still lost in translation! A correction of three misunderstandings between configurational comparativists and regressional analysts. Comparative Political Studies, 49, pp. 742774. doi: $10.1177 / 0010414014565892$

Thompson, P., 2013, Financialisation and the workplace: Extending and applying the disconnected capitalism thesis. Work, Employment and Society, 27, pp. 472-488. doi:10.1177/0950017013479827

Tomaskovic-Devey, D., Lin, K.-H. and Meyers, N., 2015, Did financialization reduce economic growth? SocioEconomic Review, 13(3), pp. 525-548. doi:10.1093/ser/mwv009

van der Zwan, N., 2014, Making sense of financialization. Socio-Economic Review, 12, pp. 99-129. doi:10.1093/ ser/mwt020

Van Rie, T., Marx, I. and Horemans, J., 2011, Ghent revisited: Unemployment insurance and union membership in Belgium and the Nordic countries. European Journal of Industrial Relations, 17, pp. 125-139. doi:10.1177/ 0959680111400895

Verkuilen, J., 2005, Assigning membership in a Fuzzy-Set analysis. Sociological Methods and Research, 33(4), pp. 462-496. doi: $10.1177 / 0049124105274498$

Vis, B., 2012, The comparative advantages of fsQCA and regression analysis for moderately large-N analyses. Sociological Methods \& Research, 41, pp. 168-198. doi:10.1177/0049124112442142

Visser, J., 2013, ICTWSS Data Base. Version 5.1 (Amsterdam: Amsterdam Institute for Advanced Labour Studies (AIAS), University of Amsterdam).

Volscho, T. W. and Kelly, N. J., 2012, The rise of the super-rich: Power resources, taxes, financial markets, and the dynamics of the top 1 percent, 1949 to 2008. American Sociological Review, 77, pp. 679-699. doi:10.1177/ 0003122412458508 


\section{Appendix}

Table A1. Summary statistics, $1975-2005$ by country (mean with SD in parentheses)

\begin{tabular}{|c|c|c|c|c|c|c|}
\hline Country & top1 & top1 change & consump & union & finref & finglob \\
\hline Australia & $\begin{array}{c}6.64 \\
(1.64)\end{array}$ & 0.167 & $\begin{array}{c}7.89 \\
(0.94)\end{array}$ & $\begin{array}{c}37.77 \\
(10.20)\end{array}$ & $\begin{array}{c}0.65 \\
(0.36)\end{array}$ & $\begin{array}{l}106.37 \\
(61.96)\end{array}$ \\
\hline Canada & $\begin{array}{c}9.70 \\
(1.89)\end{array}$ & 0.193 & $\begin{array}{c}7.27 \\
(0.64)\end{array}$ & $\begin{array}{c}33.60 \\
(2.06)\end{array}$ & $\begin{array}{c}0.85 \\
(0.14)\end{array}$ & $\begin{array}{l}154.90 \\
(62.56)\end{array}$ \\
\hline Denmark & $\begin{array}{l}5.45 \\
(.43)\end{array}$ & -0.016 & $\begin{array}{l}7.66 \\
(0.92)\end{array}$ & $\begin{array}{l}75.9 \\
(2.75)\end{array}$ & $\begin{array}{c}0.74 \\
(0.26)\end{array}$ & $\begin{array}{c}183.45 \\
(101.80)\end{array}$ \\
\hline Finland & $\begin{array}{c}5.93 \\
(1.94)\end{array}$ & 0.162 & $\begin{array}{l}7.56 \\
(0.54)\end{array}$ & $\begin{array}{l}72.80 \\
(4.67)\end{array}$ & $\begin{array}{c}0.64 \\
(0.20)\end{array}$ & $\begin{array}{c}153.51 \\
(123.47)\end{array}$ \\
\hline France & $\begin{array}{c}7.90 \\
(0.48)\end{array}$ & 0.026 & $\begin{array}{l}7.45 \\
(0.40)\end{array}$ & $\begin{array}{l}12.43 \\
(4.89)\end{array}$ & $\begin{array}{c}0.71 \\
(0.30)\end{array}$ & $\begin{array}{c}182.41 \\
(108.93)\end{array}$ \\
\hline Germany & $\begin{array}{l}10.31 \\
(0.80)\end{array}$ & 0.038 & $\begin{array}{l}7.26 \\
(1.44)\end{array}$ & $\begin{array}{c}30.81 \\
(4.83)\end{array}$ & $\begin{array}{c}0.82 \\
(0.08)\end{array}$ & $\begin{array}{c}142.63 \\
(92.20)\end{array}$ \\
\hline Ireland & $\begin{array}{c}7.76 \\
(1.71)\end{array}$ & 0.168 & $\begin{array}{l}7.30 \\
(1.94)\end{array}$ & $\begin{array}{l}53.84 \\
(9.30)\end{array}$ & $\begin{array}{c}0.81 \\
(0.20)\end{array}$ & $\begin{array}{c}577.75 \\
(591.20)\end{array}$ \\
\hline Italy & $\begin{array}{l}7.75 \\
(1.02)\end{array}$ & 0.102 & $\begin{array}{c}6.47 \\
(0.31)\end{array}$ & $\begin{array}{l}40.87 \\
(5.78)\end{array}$ & $\begin{array}{c}0.60 \\
(0.26)\end{array}$ & $\begin{array}{c}104.72 \\
(67.60)\end{array}$ \\
\hline Japan & $\begin{array}{c}7.58 \\
(0.73)\end{array}$ & 0.064 & $\begin{array}{c}5.84 \\
(0.54)\end{array}$ & $\begin{array}{l}26.33 \\
(4.60)\end{array}$ & $\begin{array}{c}0.64 \\
(0.20)\end{array}$ & $\begin{array}{l}78.34 \\
(39.79)\end{array}$ \\
\hline Korea & $\begin{array}{c}7.86 \\
(1.01)\end{array}$ & 0.071 & $\begin{array}{c}6.42 \\
(1.48)\end{array}$ & $\begin{array}{l}13.76 \\
(2.43)\end{array}$ & $\begin{array}{c}0.52 \\
(0.21)\end{array}$ & $\begin{array}{c}62.92 \\
(21.86)\end{array}$ \\
\hline Netherland & $\begin{array}{c}5.82 \\
(0.51)\end{array}$ & 0.015 & $\begin{array}{l}10.24 \\
(0.67)\end{array}$ & $\begin{array}{c}27.54 \\
(5.43)\end{array}$ & $\begin{array}{c}0.87 \\
(0.11)\end{array}$ & $\begin{array}{c}326.26 \\
(216.51)\end{array}$ \\
\hline New Zealand & $\begin{array}{c}7.50 \\
(1.92)\end{array}$ & 0.153 & $\begin{array}{c}8.46 \\
(1.25)\end{array}$ & $\begin{array}{c}43.38 \\
(18.31)\end{array}$ & $\begin{array}{c}0.73 \\
(0.29)\end{array}$ & $\begin{array}{l}128.40 \\
(63.03)\end{array}$ \\
\hline Norway & $\begin{array}{c}6.59 \\
(2.85)\end{array}$ & 0.247 & $\begin{array}{c}7.53 \\
(0.70)\end{array}$ & $\begin{array}{c}56.21 \\
(1.76)\end{array}$ & $\begin{array}{c}0.66 \\
(0.22)\end{array}$ & $\begin{array}{c}143.49 \\
(78.88)\end{array}$ \\
\hline Portugal & $\begin{array}{c}7.62 \\
(1.79)\end{array}$ & 0.164 & $\begin{array}{c}4.02 \\
(0.60)\end{array}$ & $\begin{array}{c}33.94 \\
(13.20)\end{array}$ & $\begin{array}{c}0.50 \\
(0.31)\end{array}$ & $\begin{array}{c}150.49 \\
(111.91)\end{array}$ \\
\hline Spain & $\begin{array}{c}8.16 \\
(0.38)\end{array}$ & 0.036 & $\begin{array}{c}6.47 \\
(0.58)\end{array}$ & $\begin{array}{l}16.26 \\
(8.34)\end{array}$ & $\begin{array}{c}0.73 \\
(0.24)\end{array}$ & $\begin{array}{l}107.91 \\
(79.85)\end{array}$ \\
\hline Sweden & $\begin{array}{c}4.97 \\
(0.74)\end{array}$ & 0.064 & $\begin{array}{c}8.46 \\
(0.80)\end{array}$ & $\begin{array}{l}80.62 \\
(3.75)\end{array}$ & $\begin{array}{c}0.74 \\
(0.27)\end{array}$ & $\begin{array}{c}171.78 \\
(121.46)\end{array}$ \\
\hline Switzerland & $\begin{array}{c}9.10 \\
(0.64)\end{array}$ & 0.046 & $\begin{array}{l}4.81 \\
(0.26)\end{array}$ & $\begin{array}{l}24.79 \\
(4.36)\end{array}$ & $\begin{array}{c}0.88 \\
(0.05)\end{array}$ & $\begin{array}{c}490.87 \\
(251.74)\end{array}$ \\
\hline United Kingdom & $\begin{array}{c}9.64 \\
(2.87)\end{array}$ & 0.311 & $\begin{array}{c}8.69 \\
(1.45)\end{array}$ & $\begin{array}{c}39.98 \\
(8.36)\end{array}$ & $\begin{array}{c}0.86 \\
(0.18)\end{array}$ & $\begin{array}{c}389.00 \\
(166.44)\end{array}$ \\
\hline United States & $\begin{array}{l}11.95 \\
(3.23)\end{array}$ & 0.343 & $\begin{array}{c}8.15 \\
(1.35)\end{array}$ & $\begin{array}{l}16.65 \\
(3.69)\end{array}$ & $\begin{array}{c}0.86 \\
(0.12)\end{array}$ & $\begin{array}{c}89.08 \\
(44.86)\end{array}$ \\
\hline
\end{tabular}




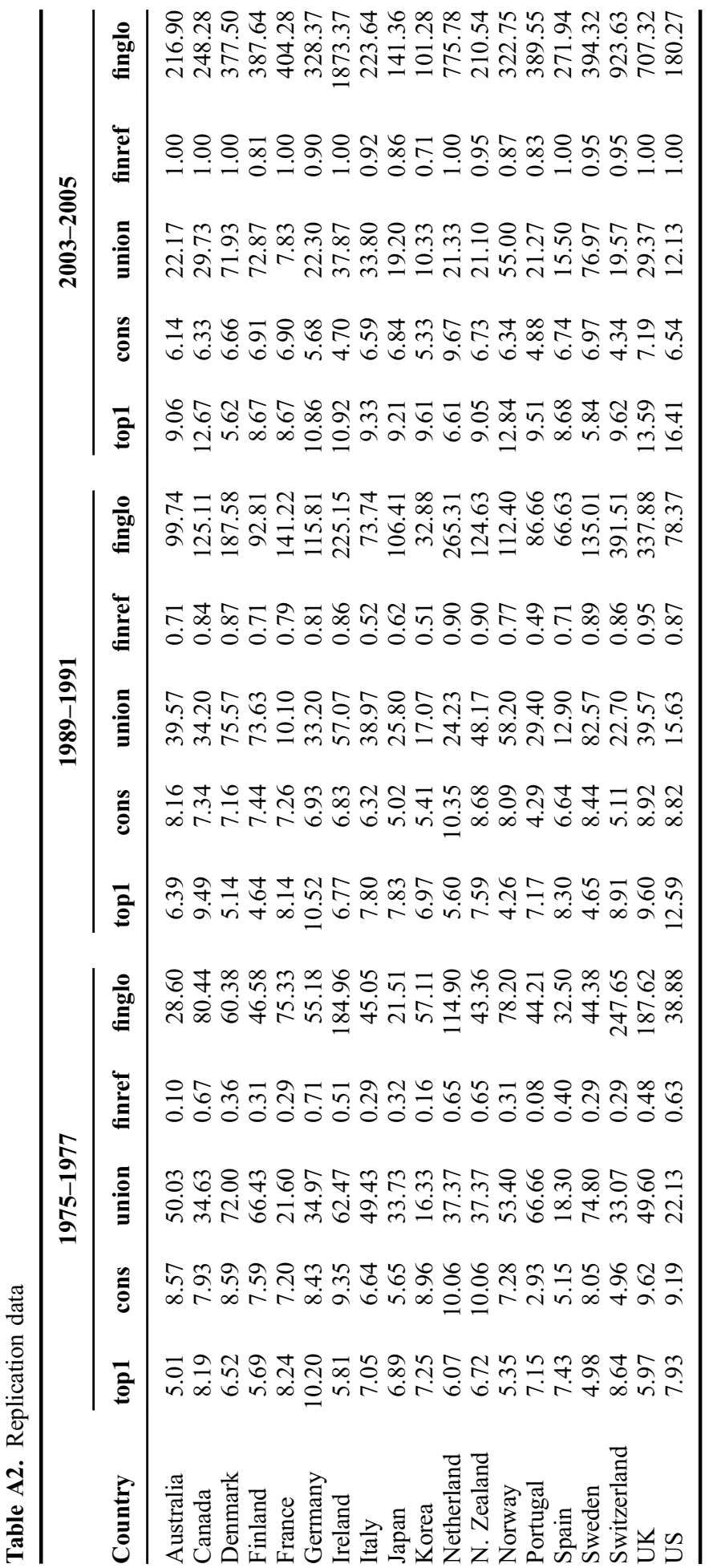




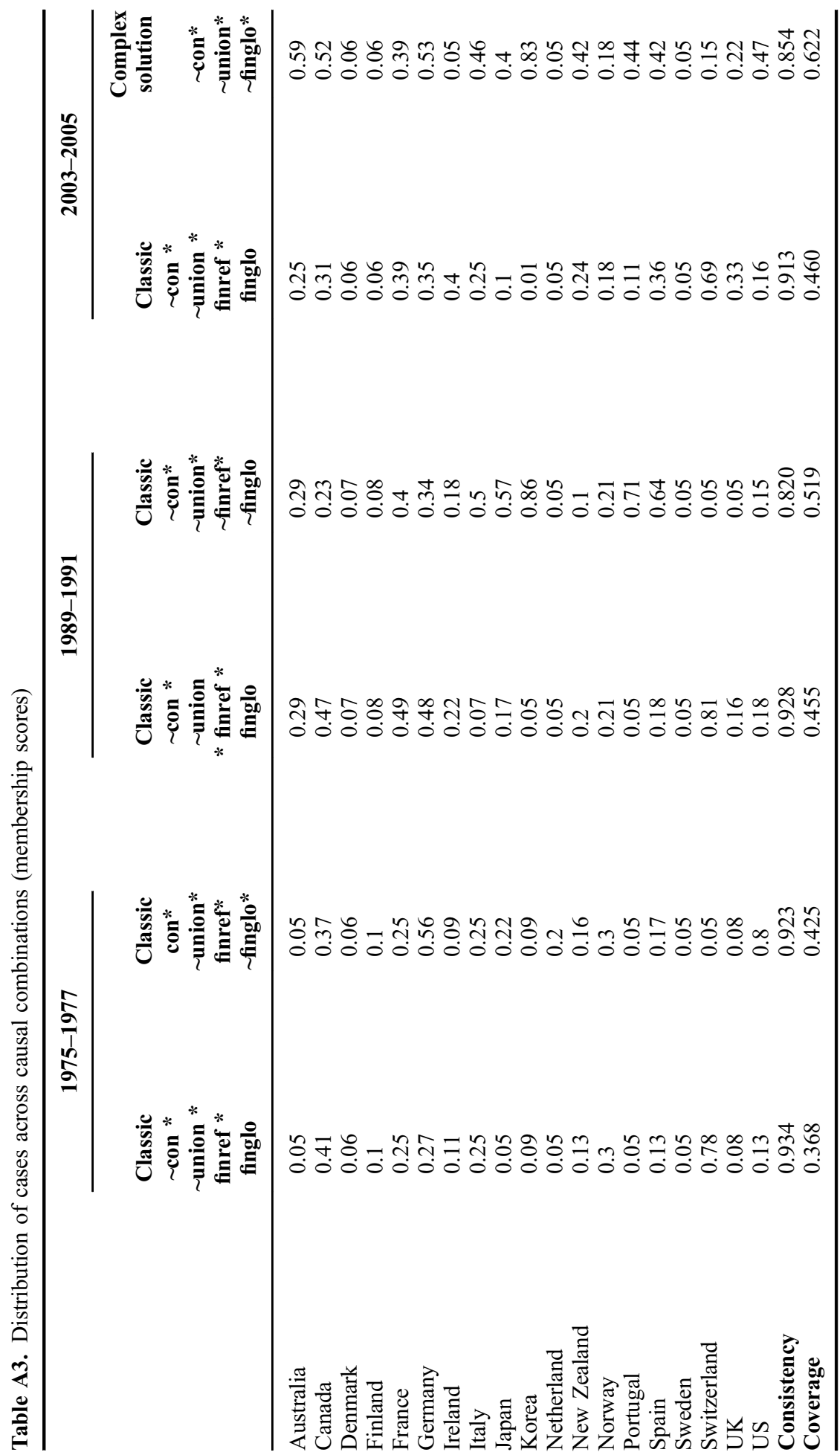




\section{E. Flaherty}

Table A4. Truth tables ( $\mathrm{n} \geq 2$, consistency $\geq 0.8$ )

\begin{tabular}{lcccccc}
\hline negcon & negunion & finref & finglob & number & top1 & consistency \\
\hline & & & $\mathbf{1 9 7 5 - 1 9 7 7}$ & & & \\
0 & 1 & 1 & 0 & 2 & 1 & 0.923 \\
1 & 1 & 0 & 0 & 2 & 1 & 0.840 \\
0 & 1 & 1 & 1 & 2 & 0 & 0.783 \\
1 & 0 & 0 & 0 & 3 & 0 & 0.652 \\
0 & 0 & 1 & 1 & 2 & 0 & 0.621 \\
0 & 0 & 0 & 0 & 4 & 0 & 0.536 \\
& & & $\mathbf{1 9 8 9 - 1 9 9 1}$ & & & \\
1 & 1 & 0 & 0 & 4 & 1 & 0.819 \\
0 & 1 & 1 & 1 & 2 & 1 & 0.808 \\
1 & 0 & 1 & 1 & 2 & 0 & 0.661 \\
0 & 0 & 1 & 1 & 3 & 0 & 0.656 \\
0 & 0 & 0 & 0 & 2 & 0 & 0.645 \\
& & & $\mathbf{2 0 0 3 - 2 0 0 5}$ & & & \\
1 & 1 & 1 & 0 & 2 & 1 & 0.891 \\
1 & 1 & 0 & 0 & 2 & 1 & 0.889 \\
0 & 1 & 1 & 0 & 3 & 1 & 0.837 \\
0 & 1 & 1 & 1 & 3 & 0 & 0.769 \\
0 & 0 & 1 & 1 & 2 & 0 & 0.708 \\
\hline
\end{tabular}

Note: The consistency column corresponds to the figures reported in the raw consist. column in fsQCA. 


\section{Appendix 4}

Figure A1. Classic combination sufficiency (1975-1977).

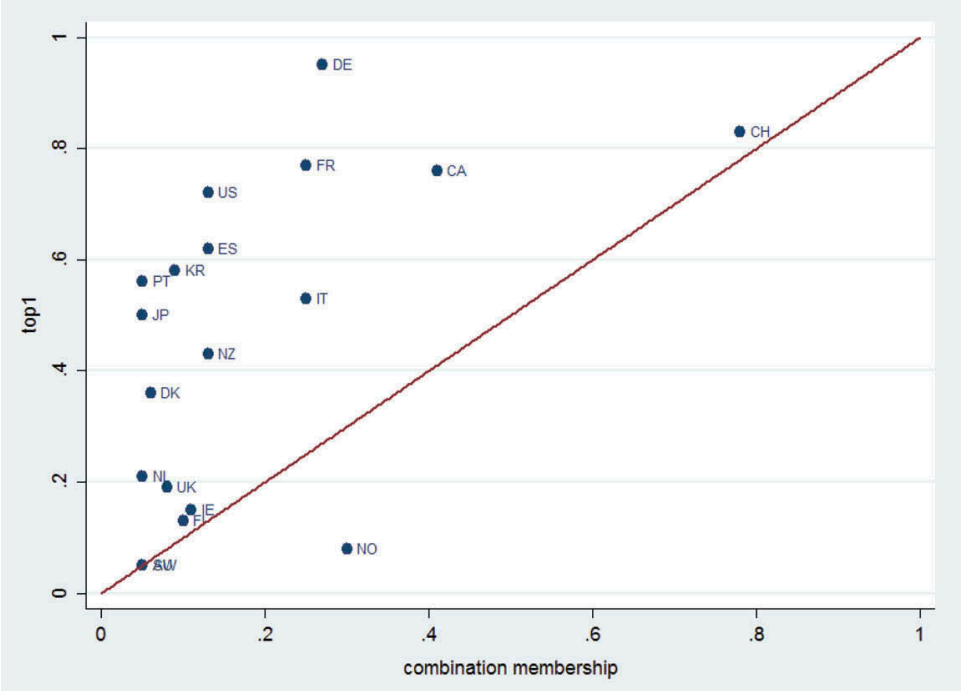

Figure A2. Classic combination sufficiency (1989-1991).

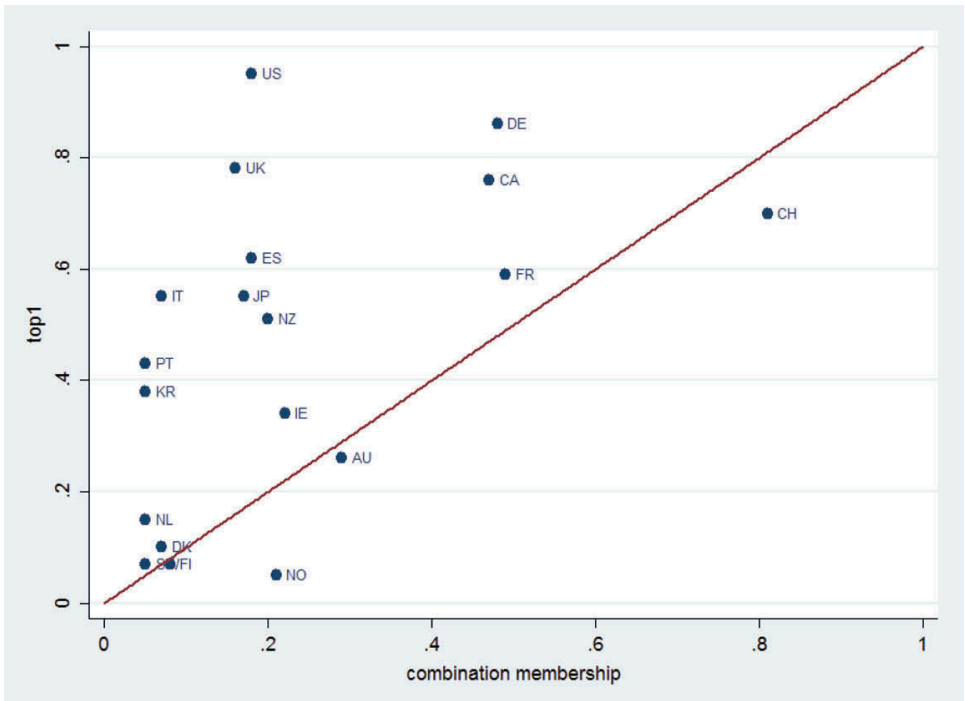

